\title{
Board Monitoring, Management Contracting and Earnings Management: An Evidence from ASX Listed Companies
}

\author{
Jinghui Liu \\ Correspondence: Jinghui Liu, Southern Cross Business School, Southern Cross University, Bilinga, QLD 4225, \\ Australia. Tel: 61-7-5589-3036. E-mail: jackie.liu@scu.edu.au
}

Received: September 12, 2012 Accepted: October 8, 2012 Online Published: October 31, 2012

doi:10.5539/ijef.v4n12p121 URL: http://dx.doi.org/10.5539/ijef.v4n12p121

\begin{abstract}
This study investigates the influence of board monitoring and management contracting on earnings management. The strengthening of corporate governance following the Enron era was designed to gain investors' confidence and ensure the truthfulness of financial information. Contracting is employed as an instrument to align the interests of agents with those of shareholders which are ultimately to maximise the value and minimise monitoring costs. By developing measures of board monitoring in accordance with the Corporate Governance Principles and Recommendations (CGPR) released by the Australian Securities Exchange (ASX) Corporate Governance Council (2009) and management contracting, this study presents evidence in an Australian context that both board monitoring and management contacting influence the extent of earnings management individually and collectively. Using a sample of 138 ASX listed companies, this study finds that discretionary accruals have shown various patterns across a range of observation periods. A higher incidence of CEO duality is significantly related to lower levels of earnings management. The independence of the boards is associated with higher levels of earnings management. The results show that managerial ownership has a positive effect on discretionary accruals. Furthermore, the impact of managerial ownership outweighs the impact of board monitoring on returned earnings, particularly on the reporting of income-increasing accruals. It is observed that the strategic shareholdings of senior management have more impact on earnings than short-term incentives. This demonstrates that long-term managerial ownership is a more effective way of aligning the interests of mangers with those of shareholders than short-term compensation such as bonus plan.
\end{abstract}

Keywords: board monitoring, corporate governance, management contracting, earnings management, discretionary accruals

\section{Introduction}

The inappropriate accounting practices and reporting irregularities of Enron and WorldCom in the US and HIH Insurance, One.Tel, and Harris Scarfe in Australia, have led the public to become sceptical and cautious about financial statements. Investors have lost confidence about the reliability of information provided by listed companies. Consequently, investors call for greater attention to establishing approaches and mechanisms that can stamp out the incidence of improper earnings management and improve the quality of reported earnings. As a result, regulatory bodies and policies-makers around the world have implemented a series of reforms, such as the Sarbanes-Oxley in U.S., the Cadbury report in U.K. and the Corporate Governance Principles and Recommendations (CGPR) in Australia. These measures are aimed at enhancing the quality of financial information. They provide guidance on specific aspects of board structures, transparency of financial reporting and the independence of auditors.

In the Australian context, the CGPR recommended that listed companies separate the roles of chairperson and CEO; establish boards of directors with a majority of outside directors; and establish corporate governance-related committees. Listed companies are required by the Listing Rule 4.10 .3 to disclose whether they comply with the CGPR. However, some variations arise across listed companies because CGPR principles are not mandatory. Therefore, one of the objectives of this study is to provide evidence about the extent to which corporate governance mechanisms impact on companies' financial reporting processes concerning discretionary accruals and ultimately patterns of earnings management.

Corporate governance, especially board monitoring, plays a role in restraining managers from manipulating earnings excessively in various ways. The key elements ensuring the effectiveness of boards' monitoring activities 
that are discussed in the literature include the proportion of outside board members, the structure of the board and its committee. It is argued that these elements will affect the strength of the boards' monitoring activities. For example, Klein (2002a) suggests that the more independent a board of directors is of the influence of the CEO, the more effective the monitoring role of the board. Therefore, it is expected that if the CEO is also the chair of the board this will affect the board's ability to monitor the decision making and business performance efficiency of the company and will have a positive impact on earnings management. Outside directors, as an important part of the corporate governance mechanism, make a contribution to achieving the objectives of the firm and to ensuring that managers act in the interests of outside stockholders (Fama, 1980; Fama \& Jensen, 1983). Consequently, if the board carries out its monitoring role effectively, the incidence of financial fraud is likely to be reduced. It has been demonstrated in a study of US firms by Beasley (1996) that the likelihood of financial statement fraud is lower for firms with a higher proportion of outside directors. Accordingly, this study examines the role of board monitoring in restraining earnings management in Australian listed companies.

Previous studies (Schipper, 1989) have found that the managements of companies implement earnings management procedures because earnings management enables companies to signal desired information regarding financial performance to the public, while maintaining rewards from the insider's perspective. Earnings management generally applies when management deliberately intervenes in the financial reporting process with the intention of obtaining some private gains. Healy and Wahlen (1999) contend that insiders conduct earnings management by modifying the firm's reported economic performance figures in order to either "mislead some stakeholders" or to "influence contractual outcomes". Baber, Kang and Liang (2005) find that management has the ability to influence the interpretations of earnings data by withholding information, especially on the composition of earnings, for which disclosure is not mandatory. If agents want to align their interests with those of shareholders, they can include negotiated provisions in their contracts that provide incentives for managers to choose accounting methods that reflect the company's underlying economic performance. This can ultimately increase the value of the company and minimise its monitoring costs (Jensen \& Meckling, 1976). Therefore, this study also investigates the impact of management contracting on earnings management in Australian listed companies.

In practice, board monitoring mechanisms and management contracting schemes, influence earnings management collectively, rather than separately. The joint impact of these two practices on earnings management shows some specific patterns regarding the extent and scope of earnings management which are of interest to investors and researchers. In particular, this study provides evidence regarding the extent to which corporate governance and management contracting scheme impact on companies' financial reporting concerning discretionary accruals and ultimately the patterns of earnings management.

Using a sample of 138 ASX listed companies, this study finds that discretionary accruals have shown various patterns across observation periods (2004-2007). A higher proportion of CEO duality is significantly related to a lower level of earnings management. The independence of the board is associated with a higher level of earnings management. The findings show that managerial ownership has a positive effect on the reporting of discretionary accruals. Furthermore, managerial ownership outweighs the effect of board monitoring regarding the restraint on returned earnings', particularly the reporting of income-increasing accruals. The impact of management contracting on earnings reported by managers is determined more by long-term shareholding in the firm than short-term incentives. This indicates that long-term managerial ownership is a more effective way to align the interests of mangers with those of shareholders than short-term incentives such as bonus plans.

The contribution of this study is threefold. First, it examines the role of board monitoring in earnings management on earnings management in an Australian context. Second, it investigates the association between management contracting and earnings management. In particular, it examined the effect on earnings reporting of various types of compensation schemes, such as long-term and short-term rewards to managers. Third, it considers the combined impact of board monitoring and management contracting on the extent of earnings management and this has not been tested in previous studies.

The structure of this paper is as follows. Section 2 reviews previous studies into board monitoring and management contracting, as well as the impact on the reductions in management's opportunistic behaviour of earnings reporting. In Section 3, hypotheses are developed based on previous research. Section 4 outlines approaches applied to measure earnings management. Section 5 introduces model development, data collection and research design. Section 6 interprets the results from univariate and multivariate analysis. Conclusions and limitations are followed in Section 7. 


\section{Literature Review}

\subsection{Board Monitoring and Earnings Management}

It is widely accepted that the board of directors plays a critical role in an effective corporate governance mechanism, particularly in overseeing top management (Fama \& Jensen, 1983), selection of senior executives (Ruigrok, Peck, Tacheva, Greve \& Hu, 2006) and the extent of voluntary disclosure of remuneration for senior executives (Liu \& Taylor, 2008). In general, corporate governance plays a role in constraining managers from manipulating earnings excessively.

Prior studies (Klein, 2002a; Peasnell, Pope \& Yong, 2005; Osma \& Noguer, 2007) have examined some key elements of boards' monitoring activities, such as the proportion of outside board members, and the structure of the board and its committee. These key elements affect the strength of the boards' monitoring activities. Klein (2002a) suggests that the more independent the board of directors is of the influence of the CEO, the more effective the monitoring done by the board. It is expected that when the CEO is also the chair of the board, this affects the CEO's ability to monitor the decision making process and performance of senior management efficiently. Therefore, CEO duality is expected to have a positive impact on earnings management. One issue about governance that is debated is whether the inclusion of outside directors in a board makes a contribution to achieving the objectives of the firm and to ensuring that managers act in the interests of outside stockholders (Fama, 1980; Fama \& Jensen, 1983). If the monitoring by the board is effective, the incidence of financial fraud is likely to be reduced. This has been identified in previous studies of US firms which indicate that the likelihood of financial statement fraud is lower for firms with a higher proportion of outside directors (Beasley, 1996).

However, the boards' monitoring is likely to show diverse patterns as the particular regulatory frameworks, institutional settings and legal environments of a company can affect board structure. For example, the study by Peasnell et al. (2005) in the U.K. finds that management efforts to turn loss into profit or to ensure that profit does not decline are constrained if the proportion of outside directors is high. However, it appears that the board will only intervene when income-increasing accrues are reported, but not when income-decreasing earnings management occurs. The role of the board of directors in limiting the incidence of earnings management tends to be performed by institutional directors in continental European settings, such as Spain (Osma \& Noguer, 2007). Osma and Noguer's study finds that the same corporate governance measures have significantly different outcomes in common-law and civil-French law countries as a result of deeply rooted differences between their legal and institutional environments. Mendez (2007) confirms that the full adoption of an Anglo-Saxon corporate governance model in the Spanish setting is inappropriate. The reason is that civil-law countries lack a tradition of a market for independent directors who enlighten regulators about the consequences of adopting these corporate governance measures. This implies that more profound institutional changes of the business culture in continental European countries are required to achieve an effective corporate governance mechanism. Furthermore, in Australia, according to Hsu and Koh (2005) the relationship between institutional investors and the level of earnings management investigated is not systematic across companies because institutional investors have diverse interests and strategies in their holdings of securities. The findings show that institutional investors mitigate aggressive earnings management when the institutions operate with long-term orientations.

To investigate the impact of corporate governance mechanisms on companies' financial reporting processes concerning discretionary accruals, this study focuses on the following aspects: the separation of the role of CEO and the chairman (CEO duality); the independence of the board of directors; and the existence and independence of a corporate governance committee.

\subsection{Management Contracting and Earnings Management}

A large number of studies have investigated the scope and nature of earnings management for a mix of business purposes. Managers have an incentive to be involved with managing the magnitude of earnings because managers can benefit from reported earnings, for example by extracting rent from shareholders (Schipper, 1989; Peasnell et al, 2005), increasing management compensation (Holthausen, Larcker \& Sloan, 1995), gaining personal benefits from divulging private information (Healy \& Palepu, 1995), and reducing political costs (Watts \& Zimmerman, 1986).

Financial reporting has a diversity of forms due to the availability of flexible options within the General Accepted Accounting Principles (GAAP). Earnings management generally applies when management deliberately intervenes in the financial reporting process (Schipper, 1989), or chooses some accounting methods in preference to others (Mazay, Wilkins, \& Zimmer, 1993), or alters firms' reported economic performance figures (Healy \& Wahlen, 1999), or influences the interpretations of earnings (Baber, et al., 2006). For example, 'income smoothing' 
and 'big bath' phenomena have been widely identified as instrumental mechanisms that occur pragmatically in the reported earnings decision-making of management.

In the discussion of information asymmetry it has been argued by Baber et al. (2006) that when managers have special information or special knowledge about the company's performance, this provides management with the ability to withhold information for which disclosure is not mandatory. However, withholding and controlling of the extent of earnings information disclosure can be costly for managers because agency costs increase when extra monitoring mechanism is imposed by the shareholders. Shareholders will price-protect themselves and monitor the behaviour of managers in order to counteract the potential costs imposed by management from the contracting perspective. A possible resolution is for participants involved in the contracts including bondholders, shareholders, and other residual claimants (as well as other managers who view their personal fortunes as closely tied to prosperity of the firm) to reach an agreement on how to compensate managers more efficiently according to performance in their contracts (Malmquist, 1990). Efficient contracting rewards managers according to available information in a way that accurately reflects the managers' contribution to the company and the company's economic performance by tying managers' remuneration to a noisy signal or the market performance of the company. The design of management contracts for senior executives may affect incentives to manage earnings regardless of corporate governance practice. These features can include the design of managerial compensation plan based on either accounting numbers or equity market performance over a long-time period.

In general, the monitoring role of the board of directors can be influenced by contracting schemes which result from both increasing managerial ownership and the existence of bonus plans. Performance-based compensation for managers compromises the ability of the board to monitor earnings management. Therefore, this study tests the effect of contracting arrangements on reported earnings. Two factors used to represent management contracting in this study are managerial ownership and the existence of bonus plans for management.

\section{Hypothesis Development}

\subsection{CEO Duality}

It is argued that the separation of roles between the CEO and the chairman of the board of directors can give the board more independence, by reducing the influence of the CEO on the board (Jensen, 1993, Klein, 2002a). Consistent with this view, the CGPR (ASX, 2003, 2007 \& 2009) recommends in Principle 2.3, that 'the roles of chairperson and CEO should not be exercised by the same individual'. This division of responsibilities between the chairperson and the chief executive officer should be agreed by the board and set out in a statement outlining position responsibilities. The chairperson is responsible for leadership of the board and the efficient organisation and conduct of the board. This will facilitate the effective contribution of all directors and promote constructive and respectful relations between board members and between the board and management. Jensen (1993) argues that the power of the CEO when that person is also a chairman of the board can provide the CEO more control over the information available. However, the study did not directly examine the effect of the separation of the role of CEO and the chairman on earnings management. Klein (2002a) suggests that the more independent the board of directors is from the influence of the CEO, the more effective the monitoring carried out by the board of directors. Although the study of Davidson, Goodwin-Stewart and Kent (2005) find no evidence of a significant negative relationship between an independent chairman and earnings management, they suggest that this may be due to limited supervision by the non-executive chairperson and to the board itself being predominantly independent from management. Based on aforementioned arguments that reduced influence of the CEO on the board is likely to lead to a decrease in earnings management because of more effective monitoring from the outsiders, the first hypothesis is established:

H1: The separation of the roles of CEO and chairman is associated with a lower level of earnings management.

\subsection{Independence of the Board of Directors}

It is discussed by Klein (2002a) and Peasnell et al. (2005) that outside directors will play a role in resolving the agency problem between managers and shareholders by the creating of employment contracts and subsequently monitoring managerial behaviours in the UK and the US. Fama (1980) and Fama and Jensen (1983) argue that outside directors are equipped with intellectual abilities and skills so they will maintain their reputation by conducting effective monitoring of the company's performance. In addition, other studies (Brickley, Coles \& Terry, 1997; McWilliams \& Sen, 1997) support the expectation that boards will be effective in helping to protect shareholders' wealth if they have a higher proportion of outside directors because outside directors can make independent judgments uninfluenced by management and opportunities. However, other studies (Chtroutou, Bedard \& Courteaul, 2001; Park \& Shin, 2004; Ebrahim, 2007) have yielded inconsistent results about earnings management and the independence of directors. This could have been due to the limited availability of information 
on the degree of independence of the directors. Therefore, the second hypothesis is developed to test how the proportion of independent directors in a board of directors affects the extent of earnings management.

H2: The higher the proportion of independent directors on the board of directors the lower the level of earnings management.

\subsection{Existence of Corporate Governance Committee}

According to the CGPR, the role of a corporate governance committee is to evaluate the effectiveness of the board in carrying out its role in corporate governance. This committee typically considers the composition of the directors, the independence of the board of directors, and the financial expertise required on the board and in each of its subcommittees. It also reviews the board's performance in strategic decision making, assesses the remuneration of senior executives, and oversees the appointment and re-appointment of committee members. It also sets the criteria for selecting the members of the committees. Therefore, it is expected that the existence of a corporate governance committee can ensure that the company has a sound corporate governance structure which can improve the quality of its monitoring and thus reduce the incidence of earnings management. Although CGPR does not include the establishment of a corporate governance committee as a specific recommendation, it is expected that companies which establish a corporate governance committee make fewer risky arrangements and perform better. Accordingly, this study tests whether corporate governance committee constrains earnings management. Hence, the third hypothesis is:

H3: The existence of a corporate governance committee is associated with a lower level of earnings management.

\subsection{Independence of the Corporate Governance Committee}

The independence of the board of directors and its sub-committees has been examined in previous studies which have investigated whether having outside directors on the board and corporate governance committee improves decision-making and the quality of reported information. A corporate governance committee is important for assessing the compliance of governance policy according to the CGPR. Following the recent market concerns about the importance of independent judgments, this study predicts that if there are more independent directors in the corporate governance committee, earnings management will be reduced. This leads to the fourth hypothesis:

H4: The higher the proportion of independent directors on the corporate governance committee, the lower the level of earnings management.

\subsection{Managerial Ownership}

Some studies argue that awarding a proportion of ordinary shares to the CEO and the senior executive to increase managerial ownership is an effective approach to constraining earnings manipulation. The shares held by the managers can therefore act as a disciplinary mechanism to align managers' interests with those of shareholders. It has been argued that a higher level of managerial ownership will reduce agency costs because managers understand that principals eventually transfer the costs to them (Jensen \& Meckling, 1976). Warfield, Wild and Wild (1995) also finds a negative relationship between managerial ownership and absolute abnormal accruals. This is because share ownership by managers leads to a closer alignment of their interests with those of shareholders, which reduces the need for the board to perform a monitoring role. Klein (2002a) suggests that although a CEO may have the power to manage reported earnings in a way that maximizes the remuneration packages of managers, the more shares the managers hold in the company, the more likely they are to act according to the outside shareholders' interests. In addition, the need for monitoring by the board of directors to ensure that the managers' interests are aligned with those of the shareholders is reduced because managers with special knowledge and information about business operations make more efficient and accountable decisions concerning the uncertain outcomes of investment decisions. However, prior research also suggests that the need for board monitoring and independence declines with managerial ownership because more managerial ownership means that managers have more negotiating power to influence board monitoring on decision making. Peasnell et al. (2005) emphasizes that the constraining effect that having a high proportion of outside directors in the board has on earning management is more pronounced. Hence, this study develops the fifth hypothesis to investigate the relationship between managerial ownership and the level of earnings management:

\section{H5: The higher the proportion of managerial ownership the lower the level of earnings management.}

\subsection{Existence of Bonus Plan}

A number of studies have investigated the association between bonus plans and choices of accounting policies. Some studies (Healy, 1985; Gaver, Gaver \& Austin, 1995; Holthausen et al., 1995) provide evidence that when managers of US firms have included bonus plans in their managerial compensation packages, they are more likely 
to exercise earnings management to maximize their bonuses. Emanuel, Wong and Wong (2003) argue that the existence of earnings-based bonus plans that provide an efficient means to legitimate the manager's decisions provides a mechanism to achieve firm value maximisation in a way which involves less opportunistic decisions. It is predicted that the existence of a bonus plan in executive' contracts is likely to increase the control over the level of earnings management.

H6: The existence of a bonus plan is associated with a higher level of earnings management.

\subsection{Control Variables}

Some control factors have been identified as distorting influences on the association between earnings management and board monitoring and management contracting. Therefore, control factors are added into the regression model to reduce the measurement errors and thus increase the validity of interpretations conducted in the hypotheses testing process.

The role of blocks of shareholders is discussed in prior studies which argue that they provide an alternative monitoring mechanism (Abbott, Park \& Parker, 2000), increase the firm's value (Roberta, 2000), and monitor the financial reporting process (Bedard, Chtourou \& Courteau, 2001). The CGPR recommends that 'companies should respect the rights of shareholders and facilitate the effective exercise of those rights'. The CGPR recommends that companies 'empower their shareholders by communicating effectively with them and giving them ready access to balanced and understandable information about the company and corporate proposals'. One way for shareholders to participate is to be represented on the board of directors which is accountable to shareholders as a matter of law. However, this mechanism breaks down and becomes sour when the managers are subservient to the shareholders representatives on the board. The alternative way to counter this situation is shareholders and institutional investors who hold large blocks of company shares to uphold the rights of all shareholders. A study conducted by Park and Shin (2004) has shown a significant association between concentrated ownership and earnings management. The findings demonstrate that block shareholders can lessen the importance of having a high proportion of independent directors on the board to constrain earnings management. However, Peasnell et al. (2000) did not provide evidence that the existence of concentrated shareholdings improves the monitoring of financial reporting. This study predicts if a company has a high proportion of block shareholders this will reduce the extent of earnings management. Therefore, it is expected that the higher the proportion of block shareholder the lower the level of earnings management.

Based on the debt-equity hypothesis, prior studies such as Dechow, Sloan and Sweeney (1996), indicate that, the higher the reliance on debt, the more likely it is that managers will engage in earnings management to avoid debt covenant violation. Klein (2002b) also indicates that firms that are close to debt covenant violation may increase earnings management. Leverage is measured by the debt-equity ratio in this study which predicts that the higher the leverage, the higher the level of earnings management.

Previous literature provides no consensus about the relationship between board size and the effective monitoring role of corporate governance. Jensen (1993) argues that with a larger board the CEO's role is more important as control mechanism. The results of Bedard et al. (2004) have shown that income-decreasing discretionary accruals are affected by board size because a larger board brings more financial expertise into the business and thus can reduce the extent of earnings management. However, a larger board is still perceived as functioning less effectively. Beasley (1996) has argued that there is a positive relationship between board size and the possibility of financial statement fraud which indicates that the larger the board, the higher the level of earnings management and thus the higher the probability of fraudulent reporting. Recent evidence provided by Vafeas (2000) supports the view that the earnings of firms with smaller boards (a minimum of five directors) is seen as more efficient by market participant, perhaps because a smaller board is adaptable and functions more efficiently than a larger board. In this study, it is predicted that board size negatively influences the level of earnings management as the company is likely to adopt recommendations voluntarily and more scrutiny is in place.

Prior research suggests that the bigger the firm, the more likely it is to use income-decreasing accruals for tax purposes and the more likely it is to avoid political visibility (Watts \& Zimmerman, 1986). Firm size also affects the structure and the size of the board (Goodwin \& Kent, 2003). Ching, Firth and Rui (2002) find that firms issuing seasoned equity offerings with larger boards have higher degrees of earnings management. It is predicted that the larger the firm size, the higher the level of earnings management.

\section{Measuring Earnings Management}

Teoh, Welch \& Wong (1998) suggest that there are three sources of earnings management: the choice of accounting method, the choice of accounting estimates, and the recognition of assets and restructuring transactions. Nelson, Elliot \& Tarpley (2000), based on their survey of audit partners and managers from one of Big 5 firms find that earnings management attempts frequently occur in reserves, revenue recognition, business combinations, 
intangibles, fixed assets, investments, leases, and compensation. The use of accrual accounting provides management the opportunity to modify earnings figures, which makes the accrual measurement as a favored empirical indicator of earnings management (Jones, 1991; Dechow et al, 1995; Teoh et al, 1998; McNichols, 2000; Peasnell et al., 2005; Wild, Subramanyam \& Halsey, 2007).

Earnings management using the aggregate accrual method is described by the Jones model (1991) and the Modified Jones model (Dechow et al, 1995) in both a time series and a cross sectional versions. The description of how to measure the total accrual in order to estimate the discretionary accruals uses both the balance sheet approach and the cash flow approach. To determine the level of earnings management in a firm, a measure of the proportion of earnings is needed which can be determined by estimating the unmanaged proportion of earnings.

The Jones model assumes that the level of gross property, plant and equipment (PPE) and the changes in revenue are the non-discretionary components of total accruals. This is because gross PPE determine the discretionary expense and the changes in revenue determine changes in working capital. The coefficients estimates ( $\beta$-beta) are used to estimate the non-managed accruals (non-discretionary accrual), and the regression residual is the measure of the managed accrual (discretionary accrual).

Where:

$$
T A C C_{i t}=\beta_{0 j}\left(1 / T A_{i t-l}\right)+\beta_{l j}\left(\Delta R E V_{i t}\right)+\beta_{2 j}\left(P P E_{i t}\right)+e_{i t}
$$

$\mathrm{TACC}_{\mathrm{it}}=$ the total accruals (net income before extraordinary items minus cash flow from operations) in year $\mathrm{t}$ for the i'th firm scaled by total assets in year $\mathrm{t}-1$

$\triangle \mathrm{REV}_{\mathrm{it}}=$ changes in revenue from ordinary activities scaled by beginning of the year total assets

$\mathrm{PPE}_{\mathrm{it}} \quad=$ property, plant and equipment (PPE) by beginning of the year total assets

$\mathrm{TA}_{\mathrm{it}}=$ total assets at the beginning of the year (BEGTA)

$\mathrm{j} \quad=$ denote firm from each industry group

$\mathrm{e}_{\mathrm{it}} \quad=$ error term

The Modified Jones model was introduced as a revision of the Jones model (Jones, 1991) which is considered to be more powerful at detecting revenue manipulation. The adjustment subtracts the changes in account receivables from the changes in revenue. This study assumes that managers have discretion over both current and long term accruals.

$$
T A C C_{i t}=\beta_{0 j}\left(1 / T A_{i t-l}\right)+\beta_{l j}\left(\Delta R E V_{i t}-\Delta R E C_{i t}\right)+\beta_{2 j}\left(P P E_{i t}\right)+e_{i t}
$$

Where

$\triangle \mathrm{REC}=$ changes in account receivables scaled by beginning of the year total assets

$\mathrm{j} \quad=$ denote firm from each industry group

$\mathrm{e}_{\mathrm{it}} \quad=$ error term

Thus, the measurement of earnings management for this study is the Jones and Modified Jones models because it captures a large portion of manipulations, it is able to measure the magnitude of earnings management, and it includes the impact of sales-based manipulation through credit sales. The discretionary accrual (DAC) is measured in two steps: firstly, the coefficient estimates of the parameter value ( $\beta$ ) from the equations (1) and (2) are determined. Second, these estimated coefficients $\left(\beta_{\mathrm{oj}}, \beta_{1 \mathrm{j}}\right.$ and $\left.\beta_{2 \mathrm{j}}\right)$ are then used in equations (3) and (4) to estimate the discretionary accrual for each sample firm by subtracting the estimate of non-discretionary accruals from the total accruals for each firm.

$$
\begin{gathered}
D A C_{i t}=T A C C_{i t}-\beta_{0 j}\left(1 / T A_{i t-1}\right)+\beta_{l j}\left(\Delta R E V_{i t}\right)+\beta_{2 j}\left(P P E_{i t}\right) \\
D A C_{i t}=T A C C_{i t}-\beta_{0 j}\left(1 / T A_{i t-1}\right)+\beta_{l j}\left(\Delta R E V_{i t}-\Delta R E C_{i t}\right)+\beta_{2 j}\left(P P E_{i t}\right)
\end{gathered}
$$

Where

$\mathrm{DAC}_{\mathrm{jt}}=$ discretionary accruals, the managed component of total accruals for sample firm $\mathrm{i}$ in industry $\mathrm{j}$ in year $\mathrm{t}$, which is equal to total discretionary accruals subtracting non-discretionary accruals.

\section{Research Method}

\subsection{Model Development}

By measuring of earning management, the association between board monitoring, management contracting and earnings management is tested in this study. As addressed in hypothesis development, the conceptual framework of the association between dependent and independent variables is shown in table 1 . 
Table 1. Summary of independent variables and their association with earnings management

\begin{tabular}{|c|c|c|c|c|}
\hline $\begin{array}{c}\text { Dependent } \\
\text { variables }\end{array}$ & Hypotheses & & Independent variables & $\begin{array}{c}\text { Association with earnings } \\
\text { management }\end{array}$ \\
\hline \multirow{10}{*}{$\begin{array}{l}\text { Earnings } \\
\text { management }\end{array}$} & \multirow{4}{*}{ Board monitoring } & H1 & CEO duality (CEOD) & - \\
\hline & & $\mathrm{H} 2$ & $\begin{array}{l}\text { Independence of the board } \\
\text { (INDBDR) }\end{array}$ & - \\
\hline & & $\mathrm{H} 3$ & $\begin{array}{l}\text { Existence of corporate governance } \\
\text { committee (ECGC) }\end{array}$ & - \\
\hline & & $\mathrm{H} 4$ & $\begin{array}{l}\text { Independence of corporate } \\
\text { governance committee (INDCGC) }\end{array}$ & - \\
\hline & \multirow{2}{*}{$\begin{array}{c}\text { Management } \\
\text { contracting }\end{array}$} & H5 & Managerial ownership (MO) & $+/-$ \\
\hline & & $\mathrm{H} 6$ & Bonus plan (BONUS) & + \\
\hline & \multirow{4}{*}{ Control variables } & & Block shareholders (BLOCK) & - \\
\hline & & & Leverage (LEV) & + \\
\hline & & & Board size (BSIZE) & - \\
\hline & & & Firm size (LNTA) & + \\
\hline
\end{tabular}

The extent of earnings management in this study is represented by discretionary accruals in an absolute term. In addition this study investigates the direction of earnings management (income-increasing or income-decreasing accruals). The estimation of discretionary accruals is using the residuals from the Jones and modified-Jones models as illustrated in equations (3) and (4) to measure earnings management. The aim of statistical analysis using these models is to identify the best linear estimates of the discretionary accruals by using the OLS regression.

The impact of board monitoring and management contracting on companies' financial reporting process concerning discretionary accruals is investigated in this study. The hypotheses developed in this study are tested in the regression model as shown in equation (5).

$$
\mathrm{DAC}=\alpha+\beta_{1} \mathrm{CEOD}+\beta_{2} \mathrm{INDBDR}+\beta_{3} \mathrm{ECGC}+\beta_{4} \mathrm{INDCGC}+\beta_{5} \mathrm{MO}+\beta_{6} \mathrm{BONUS}+\beta_{7} \mathrm{BLOCK}+\beta_{8} \mathrm{LEV}+
$$

As the demand for monitoring by the board of directors to align managers' interests with those of shareholders is reduced when managers equipped with special knowledge and information about operations of the company make more efficiently accountable decisions concerning the uncertain outcomes of investment decisions. The impact of managerial ownership upon corporate governance arrangements from earnings management perspectives is tested in equation as shown in (6):

$$
\begin{gathered}
D C A=\alpha+\beta_{1} C E O D^{*} M O+\beta_{2} I N D B D R^{*} M O+ \\
\beta_{3} E C G C^{*} M O+\beta_{4} I N D C G C^{*} M O+\beta_{5} B L O C K+\beta_{6} L E V+ \\
\beta_{7} B S I Z E+\beta_{8} L N T A+e
\end{gathered}
$$

\subsection{Data Collection}

This study examines earnings management for the period from 2004 to 2007. It is expected that companies are increasingly adopting the ASX's CGPR after its initial introduction in 2003. Therefore, a significant improvement in corporate governance is expected from firm's practice.

The selection procedure of sample companies follows two stages. The first stage involves the selection of the top 300 Australian firms by total market capitalization as $30^{\text {th }}$ June of 2007. In the second stage the firms in regulated industries (Utilities, GICS=55) and financial industries ( $\mathrm{GICS}=40)$ are excluded. This is because, first, regulated industries have a set of fixed accounting rates of return on their investment (Bughsan, 2005). Second, financial industries have applied special accounting practices that make the detection of earnings management through discretionary accruals more diverse than other sectors (Chtrourou et al., 2001; Bughsan, 2005; Peasnell et al., 2000). Third, it is also necessary to only include industries with sufficient observation to ensure unbiased estimation by using OLS regression.

The initial data of companies is collected from the ASX300 for the financial year beginning on 1 January 2003 to 31 December 2006. A total of 299 companies were included in the initial sample because their data is fully available on ASX website or on the companies' website. Companies with the GICS code of 40 (financials) and 55 (utilities) were excluded for aforementioned reasons. Companies which had missing GICS code were also excluded in order to fulfill the estimation of cross-sectional version of the Modified Jones model per industry and per year. Other companies were also excluded because of the multiple layered structure of corporate governance, presentation of financial statements in foreign currency and insufficient years. Table 2 summarizes the derivation 
of the final sample and the number of companies based on GICS code. The code of each firm is consistent with prior literature (Peasnell et al, 2000) for the estimation of discretionary accruals used in the Modified Jones model.

Table 2. Distribution of sample companies

\begin{tabular}{llll}
\hline No. & Sector & GICS code & Total observation \\
\hline 1 & Energy & 10 & 14 \\
2 & Materials & 15 & 40 \\
3 & Industrials & 20 & 24 \\
4 & Consumer Discretionary & 25 & 27 \\
5 & Consumer Staples & 30 & 16 \\
6 & Health Care & 35 & 11 \\
7 & Information Technology & 45 & 6 \\
& TOTAL & & 138 \\
\hline
\end{tabular}

The 552 annual reports of 138 observed firms in a four-year period from 2004 to 2007 are collected. Some accounting data, such as PPE, REV, REC, operating cash flow, net profit, total assets, total liabilities and total equity of sample companies are obtained from Aspect FinAnalysis for these four consecutive financial years. The board monitoring and management contracting factors, such as CEO duality (CEOD), numbers of independent directors and board of directors (INDBDR), existence and independence of corporate governance committee (ECGC and INDCGC), numbers of shares held by managers (MO), existence of bonus plan (BONUS), block shareholders (BLOCK), are manually collected from corporate governance reports and notes to financial statements of the annual reports. These annual reports are available from ASX and the company's websites.

The ordinary least squares (OLS) regression is based on matching industry that requires certain number of companies to be included in the available sample industries for analysis. If the sample is not normally distributed, increasing the sample size is a better way to avoid poor regression estimates. Eviews software allows for the use of panel least squares regression with a specification for both cross section and period fixed effect, so the discretionary accrual can be also calculated matching with the industry. It is expected that the estimation will not be significantly different because of the use of fixed effect specification in the analysis.

\section{Results}

\subsection{Descriptive Statistics for Board Monitoring and Contracting Factors and Discretionary Accruals Variables}

Table 3 shows the descriptive statistics for corporate governance and contracting characteristics, as well as discretionary accruals used in hypothesis testing.

Table 3. Descriptive statistics for board monitoring and management contracting, as well as earnings management variables

\begin{tabular}{llllllll}
\hline & $\mathrm{N}$ & Minimum & Maximum & Mean & Std. Deviation & Skewness & Kurtosis \\
\hline CEOD & 552 & 0 & 1 & .93 & .259 & -3.307 & 8.970 \\
INDBDR & 552 & 10.0000 & 100.0000 & 60.171011 & 20.0269974 & -.347 & -.835 \\
ECGC & 552 & 0 & 1 & .11 & .312 & 2.521 & 4.372 \\
INDCGC & 60 & .0000 & 100.0000 & 82.328889 & 30.4741708 & -1.768 & 2.110 \\
MO & 552 & .0000 & 67.0003 & 6.527053 & 12.9997824 & 2.566 & 6.527 \\
BONUS & 552 & 0 & 1 & .86 & .343 & -2.131 & 2.551 \\
BLOCK & 552 & .0000 & 91.6000 & 43.990254 & 19.9930518 & -.098 & -.632 \\
LEV & 552 & -1040.4901 & 2527.5047 & 107.126468 & 151.1310231 & 7.253 & 128.751 \\
BSIZE & 552 & 3 & 13 & 7.01 & 2.007 & .751 & .442 \\
TASS & 552 & 3348470 & 19183300000 & 1729001951 & 2655226627 & 3.060 & 12.081 \\
TACC & & -2.535537 & 2.574519 & -0.039179 & 0.263491 & 2.737743 & 57.28939 \\
DAC 1 & & .000148 & 1.183891 & .06054934 & & 5.995 & 47.726 \\
DAC 2 & .000113 & 1.176187 & .06248001 & & 6.096 & 49.275 \\
\hline
\end{tabular}

Where

CEOD $\quad=$ CEO duality

INDBDR $=$ the proportion of independent directors on the board of directors 


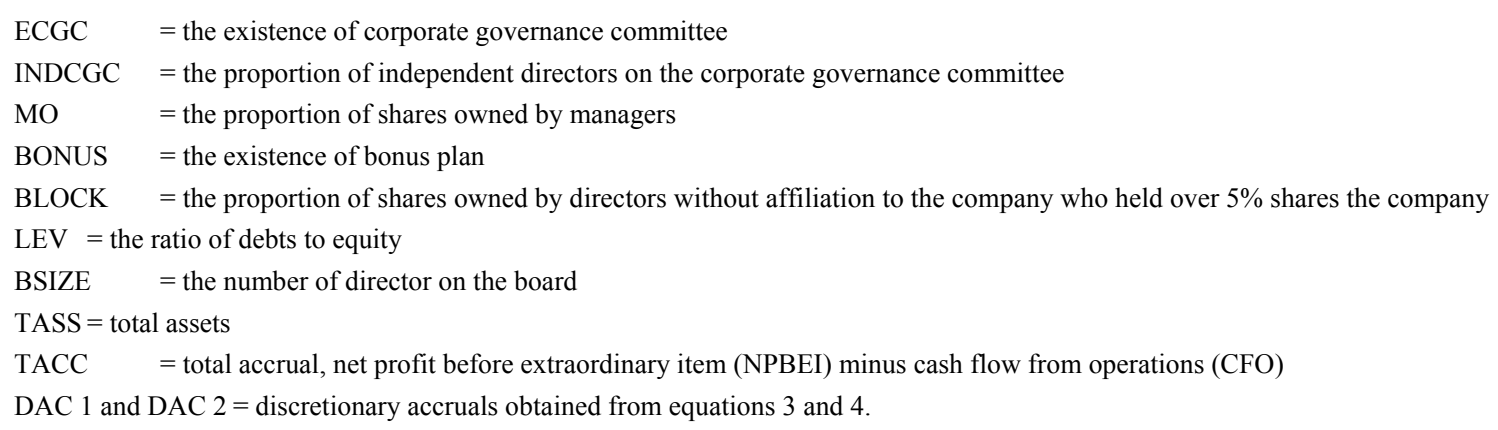

The results of table 3 show that approximately $93 \%$ of the sample companies do separate the role of CEO and the chairman (CEOD). This ratio is higher than that of U.K which is $75.5 \%$ (Peasnell et al., 2005). The average proportion of independent directors on the board of directors (INDBDR) ranges from $10 \%$ to $100 \%$. The average $(60 \%)$ is slightly higher than $58.4 \%$ in U. S. (Klein, 2002) but lower than $73.8 \%$ in U.K. (Peasnell, et al 2005). There are an increasing number of companies who establish a corporate governance committee (ECGC) from 12 in 2003 to 18 in 2007. The average proportion of independent directors on corporate governance committee (INDCGC) surges from $82 \%$. Overall, the average managerial ownership (MO) is $6.53 \%$ of total share capital with a trend of decrease over observation years. Majority of investigated companies (86\%) award managers with compensation in the form of short-term incentive and cash bonus during this period. Block shareholders (BLOCK) hold $44 \%$ of total share capital on average which is led by active transactions of institutional investors during this period. Company borrowing is increasing as leverage (LEV) measured by debt-equity ratio averages changes from $94.86 \%$ in 2004 to $135.58 \%$ in 2007 . The average of leverage (107\%) is similar to that of UK $109.7 \%$ (Klein, 2002). The average company has 7 directors in the board which is less than average British counterpart which has 8 directors on board (Klein, 2002). Total assets (TA) increase from $\$ 1417$ million to $\$ 2100.6$ million. The increased level of total assets and debts from 2004 to 2007 leads to the increase in company's leverage. Since the release of ASX CGPR, the CEO duality and independence of the board in Australian listed companies do not have significant change. However some qualitative characteristics of corporate governance, such as the role of the board and consequences on strategic oversight by board are not measured in this study which may be of importance to further study. The descriptive statistics for the DAC of the sample companies over four years are shown in table 3 as well. The TACC are scaled by total assets at the beginning of the year. DACs have demonstrated various patterns across observation periods. Earnings management has decreased significantly from 2004 to 2006, while increased from 2006 to 2007 after the adoption of the IFRS with the reclassification of PPE and revenue from operating activities. It is observed from the annual reports that, generally, restated PPE from operating activities in the annual reports of year 2007 after the adoption of the IFRS in Australian listed companies is lower than those reported in the annual reports of 2006. Many PPE were reclassified as investment assets, intangibles, or assets from business combinations.

Table 4. The Pearson correlation of independent variables

\begin{tabular}{|c|c|c|c|c|c|c|c|c|c|c|}
\hline & CEOD & INDBDR & ECGC & INDCGC & $\mathrm{MO}$ & BLOCK & BONUS & LEV & BSIZE & LNTA \\
\hline CEOD & 1 & .032 & .053 & .040 & $-.269(* *)$ & -.022 & $.093(*)$ & .050 & $.119(* *)$ & $.129(* *)$ \\
\hline INDBDR & .032 & 1 & $.201(* *)$ & $.239(* *)$ & $-.226(* *)$ & $-.290(* *)$ & .080 & $.125(* *)$ & -.027 & $.233(* *)$ \\
\hline ECGC & .053 & $.201(* *)$ & 1 & $.932(* *)$ & -.065 & .025 & $.138(* *)$ & $.144(* *)$ & $.196(* *)$ & $.299(* *)$ \\
\hline INDCGC & .040 & $.239(* *)$ & $.932(* *)$ & 1 & $-.101(*)$ & .030 & $.129(* *)$ & $.146(* *)$ & $.210(* *)$ & $.288(* *)$ \\
\hline $\mathrm{MO}$ & $-.269(* *)$ & $-.226(* *)$ & -.065 & $-.101(*)$ & 1 & .081 & $-.129(* *)$ & -.051 & $-.148(* *)$ & $-.200(* *)$ \\
\hline BLOCK & -.022 & $-.290(* *)$ & .025 & .030 & .081 & 1 & .063 & .028 & .049 & $.141(* *)$ \\
\hline BONUS & $.093(*)$ & .080 & $.138(* *)$ & $.129(* *)$ & $-.129(* *)$ & .063 & 1 & $.127(* *)$ & $.186(* *)$ & $.347(* *)$ \\
\hline LEV & .050 & $.125(* *)$ & $.144(* *)$ & $.146(* *)$ & -.051 & .028 & $.127(* *)$ & 1 & $.125(* *)$ & $.233(* *)$ \\
\hline BSIZE & $.119(* *)$ & -.027 & $.196(* *)$ & $.210(* *)$ & $-.148(* *)$ & .049 & $.186(* *)$ & $.125(* *)$ & 1 & $.575(* *)$ \\
\hline LNTA & $.129(* *)$ & $.233(* *)$ & $.299(* *)$ & $.288(* *)$ & $-.200(* *)$ & $.141(* *)$ & $.347(* *)$ & $.233(* *)$ & $.575(* *)$ & 1 \\
\hline \multicolumn{11}{|l|}{ Where } \\
\hline CEOD & \multicolumn{10}{|c|}{$=$ CEO duality } \\
\hline INDBDR & \multicolumn{10}{|c|}{$=$ the proportion of independent directors on the board of directors } \\
\hline ECGC & \multicolumn{10}{|c|}{$=$ the existence of corporate governance committee } \\
\hline INDCGC & \multicolumn{10}{|c|}{$=$ the proportion of independent directors on the corporate governance committee } \\
\hline
\end{tabular}




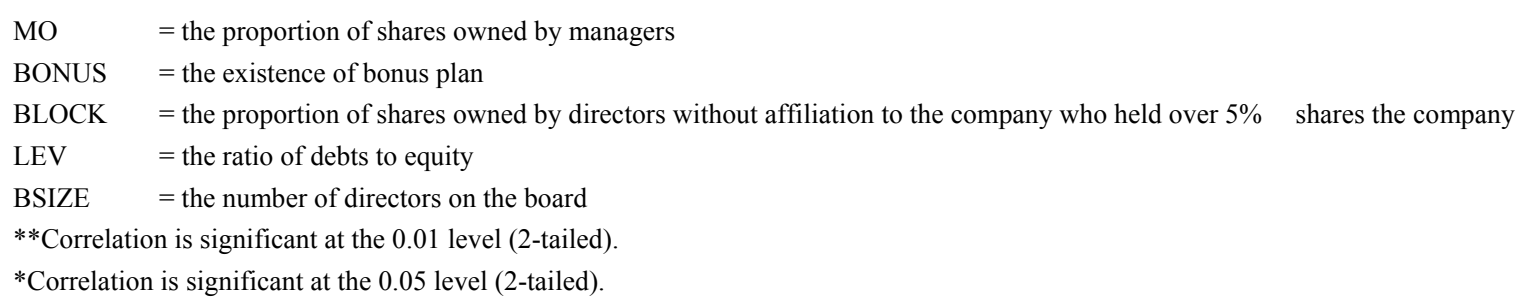

Table 4 shows the correlation of independent variables. CEOD is positively associated with BONUS and negatively associated with MO. This result indicates that if the company does not separate the role between CEO and chairman of the board, it is more likely that CEO will award managers with shares which lead to a higher level of managerial ownership. However, if the company separates the role between CEO and chairman, it is likely that the company rewards managers with more cash bonus than shareholdings possibly because the principal has the intention to reduce the potential influence on company's decisions by managers. The INDBDR is negatively associated with MO and BLOCK. This result has shown that when the independence of board of directors is higher, the proportion of shares held by senior executives and block shareholders is lower. Therefore, the company with widely held shares and less managerial ownership increases the chance to exercise independent decisions and effective corporate governance practices which is consistent with the study of Peasnell et al. (2005). There is a consistence regarding the independence between the board of directors and corporate governance committee. Table 4 also shows that MO has a negative impact on the CEOD and the independence of committees. The influence maybe twofold: first, there is less demand of corporate governance when managers hold larger proportion of shares in the company as managerial ownership is considered as an effective way to align the interests of managers with those of shareholders. Second, the more shares are held by mangers, the more impact managers have on the effectiveness of corporate governance. BONUS is positively associated with CEOD, ECGC and INDCGC and negatively associated with MO. Some companies employ cash-based compensation plan, while others prefer to share-based remuneration plan.

\subsection{Multivariate Analysis}

The equations 5 and 6 examine the relationship between earnings management to be represented by the extent of discretionary accruals (including incoming-increasing and income-decreasing accruals) and independent variables. Independent variables are factors relating to board monitoring and management contracting. Table 5 presents results of OLS regression regarding the impact of board monitoring and management contracting on earnings management. In table 5, the R-squared shows that approximately from $34.2 \%$ to $56.4 \%$ of the variation in earnings management is explained by independent variables. This suggests that the empirical model used in this study has a good fit. Therefore, the specification power of tests in this study is accepted to explain the relationship proposed.

Table 5. OLS Regression Results

Panel A: The association between earnings management and board monitoring / contracting factors

\begin{tabular}{lllllll}
\hline & Model 1 & & Model 2 & & Model 3 & \\
\hline & Beta & Sig. & Beta & Sig. & Beta & Sig. \\
\hline Constant & & .000 & & .000 & & .000 \\
CEOD & -.116 & .005 & & & -.068 & .104 \\
INDBDR & .092 & .035 & & & .155 & .001 \\
ECGC & .022 & .847 & & & -.016 & .886 \\
INDCGC & -.033 & .769 & & & -.002 & .987 \\
MO & & & .184 & .000 & .192 & .000 \\
BONUS & .092 & .765 & .014 & .745 & .019 & .647 \\
BLOCK & .244 & .587 & .017 & .674 & .065 & .133 \\
LEV & -.006 & .890 & -.003 & .951 & -.011 & .795 \\
BSIZE & .154 & .003 & .132 & .007 & .178 & .000 \\
LNTA & -.386 & .000 & -.343 & .000 & -.395 & .000 \\
R Square & .342 & & .362 & & .391 & \\
DW & 1.887 & & 1.921 & & 1.878 & \\
F & 10.266 & .000 & 13.724 & .000 & 9.736 & .000 \\
\hline
\end{tabular}


Panel B: The association between earnings management and board monitoring / contracting factors

\begin{tabular}{lllllllllll}
\hline & 2004 & & 2005 & & 2006 & & 2007 & \multicolumn{3}{c}{ ALL } \\
\hline & Beta & Sig. & Beta & Sig. & Beta & Sig. & Beta & Sig. & Beta & Sig. \\
\hline (Constant) & & .000 & & .000 & & .018 & & .004 & & .000 \\
CEODMO & -.378 & .000 & -.419 & .000 & .295 & .018 & .129 & .316 & -.151 & .009 \\
INDBDRMO & .513 & .000 & .488 & .000 & .080 & .519 & .088 & .498 & .349 & .000 \\
ECGCMO & -.016 & .912 & .009 & .953 & -.098 & .574 & .071 & .719 & -.001 & .990 \\
INDCGCMO & -.042 & .766 & -.040 & .797 & .019 & .919 & -.122 & .532 & -.059 & .452 \\
BLOCK & .056 & .761 & .062 & .478 & .047 & .743 & .052 & .543 & .0465 & .561 \\
LEV & .089 & .245 & .027 & .748 & -.071 & .472 & -.020 & .808 & .007 & .856 \\
BSIZE & .311 & .001 & .260 & .010 & .084 & .413 & -.048 & .640 & .173 & .000 \\
LNTA & -.466 & .000 & -.391 & .000 & -.209 & .043 & -.229 & .026 & -.325 & .000 \\
R Square & .564 & & .492 & & .426 & & .366 & & .400 & \\
DW & 1.758 & & 1.861 & & 1.706 & & 2.039 & & 1.874 & .000 \\
F & 8.614 & .000 & 5.881 & .000 & 4.089 & .000 & 2.868 & .000 & 14.681 & .000 \\
\hline
\end{tabular}

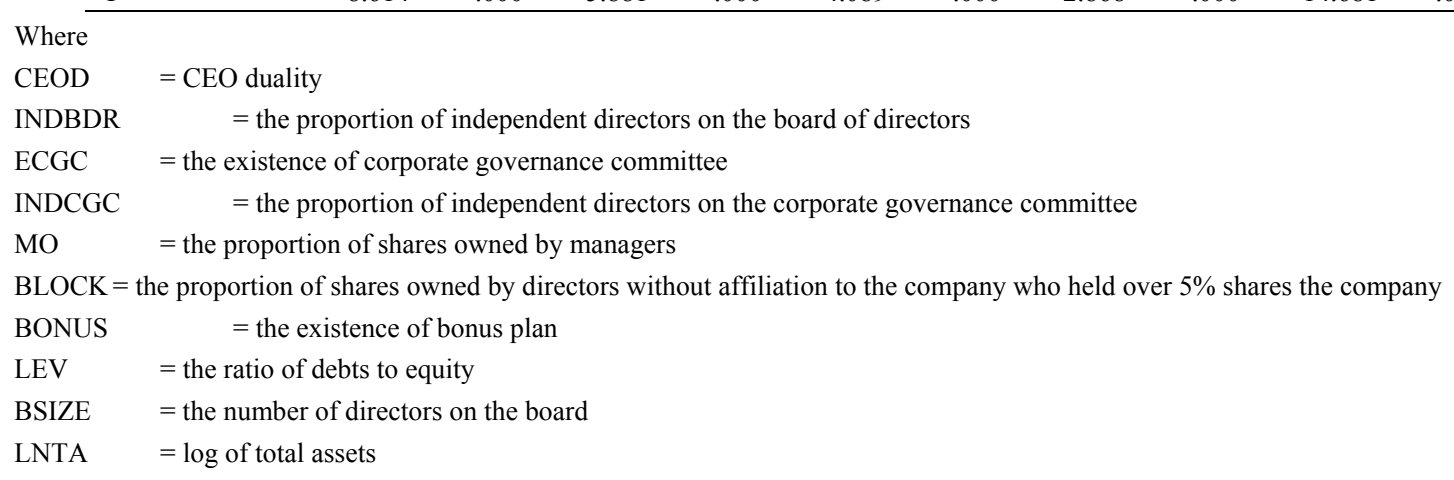

The results of model 1 in the panel A of table 5 examines the effect of board monitoring upon earnings management. Model 2 investigates the influence of management contracting upon earnings management. Incorporation of board monitoring and management contracting are shown in Model 3. The results show that earnings management is negatively associated with CEOD and LNTA, while positively associated with INDBDR and BSIZE. CEOD is an effective corporate mechanism to constrain manager's incentive to manage reported earnings. This finding supports $\mathrm{H} 1$ that $\mathrm{CEO}$ duality will affect reported earnings. The result of this study regarding the independence of the board (H2) is opposite to the findings of Peasnell et al. (2005) Klein (2002) in US and in UK. The possible reason may be because directors are more focused on the market performance of companies with the intention to reduce the impact of volatility. This reflects that investors in Australia are more cautious with a preference to evaluate corporate performance and position more conservatively when there are more market speculations regarding investment. $\mathrm{H} 3$ and $\mathrm{H} 4$ are not identified by the results. The role of corporate governance committee maybe combined with other functions of the board. MO plays a significant role in earnings management, while BONUS does not. This shows that awarding shares to managers in Australia companies is demonstrated to be a more effective mechanism (H5) than cash-based compensation (H6) to encourage managers to take favorable actions aligning their interests with those of shareholders. This is consistent with the results of Mazay, et al. (1993) and Emanuel, et al. (2003).

The results shown in panel $\mathrm{B}$ of table 5 demonstrate joint influence of board monitoring mechanism and managerial contracting on earnings management. The results indicate that earnings management is negatively associated with CEODMO and LNTA, while positively associated with INDBDRMO and BSIZE from all sample companies. However this impact is not consistent over the observation period of 2004-2007. CEODMO is positively associated with earnings management in 2006, while none parameter affects earnings management in 2007. One of the explanations of these results is that there are changes regarding the pattern of reported earnings in 2006 and 2007. Companies are expecting the adoption of the IFRS in 2006 and the adoption of the IFRS do have impact on the reporting of earnings information. Therefore, management contracting will outweigh the decision of the board of directors regarding reported earnings when there are unexpected outcomes about accounting standards. 
Table 6. The association between income-increasing and income-decreasing earnings management and board monitoring / contracting factors

\begin{tabular}{|c|c|c|c|c|c|c|c|c|c|c|}
\hline & & \multicolumn{2}{|c|}{$\begin{array}{l}\text { Income-increasing } \\
\text { model } 1\end{array}$} & \multicolumn{2}{|c|}{$\begin{array}{l}\text { Income-decreasing } \\
\text { model } 2\end{array}$} & & \multicolumn{2}{|c|}{$\begin{array}{l}\text { Income-increasing } \\
\text { model } 3\end{array}$} & \multicolumn{2}{|c|}{$\begin{array}{l}\text { Income-decreasing } \\
\text { model } 4\end{array}$} \\
\hline & & Beta & Sig. & Beta & Sig. & & Sig. & Sig. & Beta & Sig. \\
\hline Constant & & & .000 & & .134 & Constant & & .000 & & .046 \\
\hline CEOD & & -.134 & .004 & .125 & .187 & CEODMO & -.425 & .000 & .324 & .006 \\
\hline INDBDR & & .178 & .001 & .051 & .599 & INDBDRMO & .609 & .000 & -.030 & .797 \\
\hline ECGC & & -.036 & .753 & -.004 & .989 & ECGCMO & -.034 & .657 & .056 & .810 \\
\hline INDCGC & & .018 & .880 & -.012 & .970 & INDCGCMO & -.025 & .746 & -.170 & .451 \\
\hline MO & & .192 & .000 & .241 & .011 & & & & & \\
\hline BONUS & & .013 & .784 & -.034 & .728 & & & & & \\
\hline BLOCK & & .065 & .188 & .066 & .461 & BLOCK & .085 & .235 & .089 & .675 \\
\hline LEV & & -.004 & .934 & -.063 & .496 & LEV & .007 & .868 & -.048 & .625 \\
\hline BSIZE & & .195 & .001 & .078 & .485 & BSIZE & .195 & .000 & .070 & .517 \\
\hline LNTA & & -.421 & .000 & -.192 & .130 & LNTA & -.315 & .000 & -.169 & .112 \\
\hline R Square & & .447 & & .269 & & R Square & .510 & & .339 & \\
\hline DW & & 1.816 & & 2.037 & & DW & 1.761 & & 2.101 & \\
\hline $\mathrm{F}$ & & 9.722 & .000 & 1.258 & .261 & $\mathrm{~F}$ & 19.623 & .000 & 2.475 & .020 \\
\hline \multicolumn{11}{|c|}{ Where } \\
\hline OD & & \multicolumn{9}{|c|}{$=\mathrm{CEO}$ duality } \\
\hline DBDR & & \multicolumn{9}{|c|}{$=$ the proportion of independent directors on the board of directors } \\
\hline $\mathrm{GC}$ & & \multicolumn{9}{|c|}{$=$ the existence of corporate governance committee } \\
\hline DCGC & & \multicolumn{9}{|c|}{$=$ the proportion of independent directors on the corporate governance committee } \\
\hline & \multicolumn{10}{|c|}{$=$ the proportion of shares owned by managers } \\
\hline OCK & \multicolumn{10}{|c|}{$=$ the proportion of shares owned by directors without affiliation to the company who held over $5 \%$ shares the company } \\
\hline NUS & \multicolumn{10}{|c|}{$=$ the existence of bonus plan } \\
\hline $\mathrm{V}$ & \multicolumn{10}{|c|}{$=$ the ratio of debts to equity } \\
\hline IZE & & \multicolumn{9}{|c|}{$=$ the number of directors on the board } \\
\hline ITA & & \multicolumn{9}{|c|}{$=\log$ of total assets } \\
\hline
\end{tabular}

The table 6 shows how managerial contracting and board monitoring impact on the decision of income-increasing and income-decreasing accruals. The results of Model 1 show that incoming-increasing accruals are negatively associated with CEOD and LNTA, while positively associated with INDBDR, MO and BSIZE. However, income-decreasing accruals are not influenced by board monitoring and management contracting as shown in Model 2 of table 6. The joint influence of board monitoring and management contracting are shown in Models 3 and 4 of table 6. CEODMO has a positive impact on the incremental reported earnings. This shows that the influence of management contracting and board monitoring is more likely to be involved with income-increasing rather than income-decreasing accruals and this result is consistent with the study of Peasnell et al. (2005). The impact of managerial contracting on earnings outweighs the decision of the board of directors. This finding confirms the statement made by Peasnell et al. (2005) that increasing ownership of managers in a firm will reduce the effectiveness of corporate governance from the view point of earnings management.

The findings of this study show that the existence and the independence of corporate governance committee do not restrain the possibility for managers to choose their favorite accounting policies of reported earnings. Therefore, $\mathrm{H} 3$ and $\mathrm{H} 4$ are rejected. It is suggested that the contribution of corporate arrangement, particularly by independent directors, to promote constructive relations among board members and between the board and management need to be implemented effectively in a corporate structure. Furthermore, this study finds that block shareholders do not practise activism directly regarding earnings management. The reason maybe is because block shareholders, particularly institutional shareholders, do not have systematic interests and strategies across invested companies. Block shareholders is likely interested in mitigation of aggressive earnings management only when they operate with long-term orientations and this is consistent with the results of Kothari, Leone and Wasley (2005).

\section{Conclusions}

The study investigates the associate between board monitoring, management contracting and earnings management. Using a sample of 138 ASX listed companies, this study finds that discretionary accruals have 
shown various patterns across observation periods. Earning managements decreased significantly from 2004 to 2007, and increased from 2006 to 2007 after the adoption of the IFRS with the reclassification of PPE and revenue from operating activities. A higher proportion of CEO duality is significantly related to a lower level of earnings management. However, managerial ownership outweighs this effect when it comes to the adoption of the IFRS and income-increasing management. The independence of the board is positively associated with a higher level of earnings management, possibly because the board has the intention of reducing the volatility of share prices. It is found that management contracting has an impact on the manipulation of earnings information. This impact on earnings management by managers is determined more by the level of their shareholdings in the firm. This is because long-term ownership and share-based compensation schemes are more effective ways of aligning the interests of mangers with those of shareholders than short-term compensation and cash-based incentive schemes such as bonus plans. It is recommended that firms should use share-based compensation schemes carefully as which may lead to irresponsible decisions regarding corporate proposals and this may outweigh the benefit of firms' investment opportunities. Therefore, firms should implement effective corporate mechanisms to monitor opportunistic activities with a focus on qualitative settings rather than quantitative settings. Block shareholders are not an effective mechanism in constraining earnings management.

This study has some limitations. First, it should be noted that its findings are heavily dependent on the accuracy of discretionary accrual estimates used to represent earnings management. The difficulty of accurately separating total accruals into discretionary and non-discretionary components in the Jones and Modified Jones models can lead to some degree of inaccuracies. This can be improved by using a combination of the models developed by Teoh et al. (1998), Peasnell et al. (2005) and Kothari et al. (2005) to test the robustness of the model. Second, although this study aims to test the effectiveness of the recommendations of the CGPR, the results could be biased because some variables correlated with the characteristics of corporate governance are omitted in the model and they could have an influence on earnings management. Third, the sample companies used in this study were selected from the ASX300. Thus, it should be acknowledged that the results may not be generalizable to all Australian companies, especially smaller and private (unlisted) companies. Fourth, it has been argued that earnings management can also be beneficial to shareholders if it is used for signaling "good news" (Subramayam, 1996). However, this aspect of earnings management has not been examined in this study.

\section{Acknowledgements}

The author acknowledges the research and financial support provided by The University of Adelaide. In addition, the author would like to thanks the helpful comments from Dennis Taylor, Howard Philp, Bryan Howieson, Janice Loftus, Kate Harris, Ian Eddie, and participants at the special group meeting of Accounting and Finance Association in Australia and New Zealand Conference. The author wishes to thank Nora Oraini for data collection. The author appreciates John Revington for proofreading.

\section{References}

Abbott, L.J., Park, Y., \& Parker, S. (2000). The Effects of Audit Committee Activity and Independence on Corporate Fraud. Managerial Finance, 26, 55-67, http://dx.doi.org/10.1108/03074350010766990

ASX CGPR. (2003). Principles of Good Corporate Governance and Best Practice Recommendations (1st edition).

ASX CGPR. (2007). Corporate Governance Principles and Recommendations (2nd edition).

ASX CGPR, (2009). Corporate Governance Principles and Recommendations (3rd edition).

Baber, W. R., Kang, S. H., \& Liang, L. (2005). Strong boards, management entrenchment and accounting restatement, The George University, School of Business, retrieved from zsbapp.baruch.cuny.edu/download/Accountancy/BKLJuly20.pdf

Beasley, M. (1996). An empirical analysis of the relation between the board of directors composition and financial statement fraud. Accounting Review, 71(4), 443-465.

Bedard, J., Chtourou, S., \& Courteau, L. (2004). The effect of audit committee expertise, independence, and activity on aggressive earnings management. Auditing: A Journal of Practice \& Theory, 23, 13-35.

Brickley, J., Coles, J., \& Terry, R. (1994). Outside directors and the adoption of poison pills. Journal of Financial Economics, 35(1), 371-32. http://dx.doi.org/10.1016/0304-405X(94)90038-8

Bugshan, T. O. (2005). Corporate Governance, Earnings Management and the Information Content of Accounting Earnings: Theoretical Model and Empirical Tests, PhD, unpublished, ePublications@Bond University, Faculty of Business. 
Ching, K., Firth, M., \& Rui, O.M. (2002). Earnings management, corporate governance and the market performance of seasoned equity offerings, retrieved from SSRN: http://ssrn.com/abstract=337880

Chtourou, S. M., Bedard, J., \& Courteau, L. (2001). Corporate governance \& earnings management, Working paper, University of Laval, Canada, retrieved from http://papers.ssrn.com/abstract=275053

Davidson, R., Goodwin-Stewart, J., \& Kent, P. (2005). Internal governance structures and earnings management. Accounting and Finance, 45(2), 241-267. http://dx.doi.org/10.1111/j.1467-629x.2004.00132.x

Dechow, P. M., Sloan, R. G., \& Sweeney, A. P. (1995). Detecting earnings management, Accounting Review, 70, 193-225.

Dechow, P. M., Sloan, R. G., \& Sweeney, A. P. (1996). Causes and consequences of earnings manipulation: an analysis of firms subject to enforcement by the SEC. Contemporary Accounting Research, 13, 1-36. http://dx.doi.org/10.1111/j.1911-3846.1996.tb00489.x

Ebrahim, A. (2007). Earnings management and board activity: An additional evidence. Review of Accounting \& Finance, 6(1), 42-58. http://dx.doi.org/10.1108/14757700710725458

Emanuel, D., Wong, J., \& Wong, N. (2003). Efficient contracting and accounting. Accounting and Finance, 43, 149-166. http://dx.doi.org/10.1111/1467-629X.00086

Fama, E. F., \& Jensen, M. C. (1983), Separation of ownership and control, Journal of Law and Economics, 26, 301-25. http://dx.doi.org/10.1086/467037

Fama, E. F. (1980). Agency problems and the theory of the firm. Journal of Political Economy, 88(2), 288-307. http://dx.doi.org/10.1086/260866

Gaver, J. J., Gaver, K. M., \& Austin, J. R. (1995). Additional Evidence on Bonus Plan and Earnings Management. Journal of Accounting \& Economics, 19, 3-28. http://dx.doi.org/10.1016/0165-4101(94)00358-C

Goodwin, J., \& Kent, P. (2003). Factors affecting the voluntary use of internal audit, working paper, University of Queensland, St. Lucia/ Queensland University of Technology, Brisbane. retrieved from espace.uq.edu.au/eserv/UQ:76832/Kent_MAJ21_1_.pdf

Healy, P. (1985). The effect of bonus scheme on accounting decision. Journal of Accounting \& Economics, 7(1-3), 85-107.

Healy, P. M., \& Wahlen, J. M. (1999). A review of earnings management literature and its implications for standard setting. Accounting Horizon, 13(4), 365-383. http://dx.doi.org/10.2308/acch.1999.13.4.365

Healy, P., \& Palepu, K. (1995). The challenges of investor communication. Journal of Financial Economics, 38 , 111-140. http://dx.doi.org/10.1016/0304-405X(94)00814-H

Holthausen, R. W., D. Larcker, \& R. Sloan. (1995). Annual bonus schemes and the manipulation of earnings. Journal of Accounting and Economics, 19(1), 29-74. http://dx.doi.org/10.1016/0165-4101(94)00376-G

Hsu, G., \& Koh, P. (2005). Does the presence of institutional investors influence accruals managements? Evidence from Australia. Corporate Governance, 13, 809-823. http://dx.doi.org/10.1111/j.1467-8683.2005.00472.x

Jensen, M. C. (1993). The modern industrial revolution, exit and the failure of the internal control system. Journal of Finance, 48, 831-880. http://dx.doi.org/10.1111/j.1540-6261.1993.tb04022.x

Jensen, M., \& Meckling, W. (1976). Theory of the firm: managerial behaviour, agency costs and ownership structure. Journal of Financial Economics, 305-360. http://dx.doi.org/10.1016/0304-405X(76)90026-X

Jones, J. (1991). Earnings management during import relief investigations. Journal of Accounting Research, 29(2), 193-228. http://dx.doi.org/10.2307/2491047

Klein, A. (2002a). Audit committee, board of director characteristics, and earnings management. Journal of Accounting \& Economics, 33(3), 374-400. http://dx.doi.org/10.1016/S0165-4101(02)00059-9

Klein, A. (2002b). Economic determinants of audit committee independence. Accounting Review, 2, 435-452. http://dx.doi.org/10.2308/accr.2002.77.2.435

Kothari, S. P., Leone, A. J., \& Wasley, C. E. (2005). Performance Matched Discretionary Accrual Measures. Journal of Accounting and Economics, 39, 63-197. http://dx.doi.org/10.1016/j.jacceco.2004.11.002

Liu, J., \& Taylor, D. (2008). Legitimacy and corporate governance determinants of executives' remuneration disclosure. Corporate Governance, the International Journal of Society, 8(1), 59-72. 
Malmquist, D. (1990). Efficient contracting and the choice of accounting method in the oil and gas industry. Journal of Accounting and Economics, 12, 173-205. http://dx.doi.org/10.1016/0165-4101(90)90046-7

Mazay, V., Wilkins, T., \& Zimmer, I. (1993). Determinants of the choice for investments in associated companies. Contemporary Accounting Research, 10, 31-59. http://dx.doi.org/10.1111/j.1911-3846.1993.tb00381.x

McNichols, M. F. (2000). Research design issues in earnings management studies. Journal of Accounting \& Public Policy, 19(4/5), 313-345. http://dx.doi.org/10.1016/S0278-4254(00)00018-1

McWilliams, V., \& Sen, N. (1997). Board monitoring and antitakeover amendments. Journal of Financial and Quantitative Analysis, 32(4), 491-505. http://dx.doi.org/10.2307/2331234

Nelson, M. W., Elliot, J. A., \& Tarpley, R. L. (2000). Where do companies attempt earnings management, and when do auditors prevent it, AFA 2001 New Orleans Meetings, available at SSRN: http://ssrn.com/abstract=248129

Osma, B., \& Noguer, B. (2007). The effect of the board composition and its monitoring committees on earnings management: Evidence from Spain. Corporate Governance, 15, 1413-1427. http://dx.doi.org/10.1111/j.1467-8683.2007.00654.x

Park, Y. W., \& Shin, H. H. (2004). Board Composition and Earnings Management in Canada, Journal of Corporate Finance, 10, 431-457. http://dx.doi.org/10.1016/S0929-1199(03)00025-7

Peasnell, K. V., Pope, P. F., \& Young, S. (2005). Board monitoring and earnings management: Do outside directors influence abnormal accruals? Journal of Business Finance \& Accounting, 32, 1311-1346. http://dx.doi.org/10.1111/j.0306-686X.2005.00630.x

Roberta, R. (2000). Less is more: Making shareholder activism a valued mechanism of corporate governance, Source: Working Papers, Yale School of Management's Financial Research Network, retrieved from http://www.ecgi.org/activism/index.php

Ruigrok, W., Peck, S., Tacheva, S., Greve, P. \& Hu, Y. (2006). The determinants and effects of board nomination committees, Journal of Management and Governance, 10(2), 119-148. http://dx.doi.org/10.1007/s10997-006-0001-3

Schipper, K. (1989). Commentary on earnings management. Accounting Horizons, 3, 91-102.

Subramanyam, K. R. (1996). The pricing of discretionary accruals. Journal of Accounting \& Economics, 22 (1-3), 249-81. http://dx.doi.org/10.1016/S0165-4101(96)00434-X

Teoh, S. H., Welch, I., \& Wong, T. J. (1998). Earnings management and the long-run market performance of initial public offering. Journal of Finance, 53, 1935-1975. http://dx.doi.org/10.1111/0022-1082.00079

Vafeas, N. (2000). Board structure and the informativeness of earnings. Journal of Accounting and Public Policy, 19(2), 139-160. http://dx.doi.org/10.1016/S0278-4254(00)00006-5

Warfield, T. D., Wild, J. J., \&Wild, K. L. (1995). Managerial ownership, accounting choices and informativeness of earnings. Journal of Accounting and Economics, 20, 61-92. http://dx.doi.org/10.1016/0165-4101(94)00393-J

Watts, R., \& Zimmerman, J. L. (1986). Positive Accounting Theory. Englewood-Cliffs, N. J.: Prentice Hall, Inc.

Wild, J. J., Subramanyam, K. R., \& Halsey, R. F. (2007). Financial Statement Analysis. McGraw-Hill Publishing Company Ltd. 